\title{
A Study of Aging Population and Central Provident Fund System in Macao
}

\author{
Tang, Kai Hong \\ Independent Scholar \\ Macau, Macau China \\ E-mail: samtangkh@yahoo.com.hk
}

Received: Jun. 20, 2017 Accepted: Jan. 29, 2018 Online published: Feb. 6, 2018

doi:10.5296/jpag.v8i1.12622ＵRL: https://doi.org/10.5296/jpag.v8i1.12622

\begin{abstract}
The world's overall fertility rate is declining while the life expectancy is increasing, the population structure is aging, the dependency ratio in Macao will steadily increase to $38.6 \%$ at the end of 2036. The median age of Macao is rising from Aged 38.1 to 45.5 during the period of 2011 to 2036. In this view, Macao becomes the aging society.

In order to establish a basis for the establishment of a central provident fund system, the Macao SAR Government implemented the central savings system in 2009 through the General Rules for the Establishment and Management of Individual Accounts of the Central Savings System through Administrative Regulation No. 31/2009 to allocate funds for eligible account holders, Subsequently, the Government of the Macao Special Administrative Region (SAR) promulgated the Act "Non-mandatory Central Provident Fund System" .
\end{abstract}

Keywords: Macao, aging population, central provident fund, public policy

\section{Introduction}

The aging of the global population is the trend of the times, the proportion of the world's population over the age of 65 is accelerating. According to the US Census Bureau in March 2016, the global population is aging at an unprecedented rate, according to its statistics, the current global population over the age of 65 accounted for $8.5 \%$ of the global population, more than 600 million. However, according to the current trend, the population that over the age of 65 will have 1.6 billion people by 2050 , accounting for $17 \%$. The study shows that the world's average life expectancy will increase from 68.6 in 2015 to 76.2 by 2050, "super-elderly population" which over the age of 80 will also increase significantly from 1.26 billion in 2015 to 4.466 Billion by 2050 . 
The second tier of social security system is the central provident fund system. The purpose of this system is to provide further social security for the residents on the basis of the first tier.

For the establishment of a central provident fund system, the Macao SAR Government implemented the central savings system in 2009 through the General Rules for the Establishment and Management of Individual Accounts of the Central Savings System through Administrative Regulation No. 31/2009 to allocate funds for eligible account holders, Subsequently, the Macao Government promulgated the Act "Provident Fund Individual Accounts" of Law No. 14/2012, which further refined the relevant funding mechanism to regulate the annual provident fund of the eligible account holders in the event of a financial budget permit (including funds), as well as the mandatory basic payments (start-up payments) of MOP \$ 10000 for the first-time eligible account holders.

In April 2014, the Macao SAR Government conducted a 60-day public consultation on the "Non-mandatory central provident fund system", which recommended that employees (and employers) participate in the donation scheme jointly or personally. The scheme will be used to invest in government-approved pension funds for value-added, while the account balance will not be due to the end of the labor relationship was settled and the extraction of "Non-mandatory central provident fund system" draft law on June 21, 2016 that be formally adopted by the Legislative Council and will be formally implemented after the completion of the detailed discussion.

\subsection{Macao's Aging Population}

Macao is defined as 65 years old as a retirement age and accepted for elders' medical benefits and pension benefits. Therefore, Macao is accustomed to defining aged 65 and above as elderly. According to the population data by Macao Statistics and Census Service, the total population of Macao was 650834 in August 2016, with an increase of 17.8\% over 552503 in the 2011, mainly due to the substantial increase in the number of overseas employees and the rise in the birth rate. The average annual growth rate of the population of Macao was 3.3\% from 2011 to 2016, the highest in the past two decades. Excluding the local population of foreign workers and foreign students, there were 537018 people, with an increase in $10.7 \%$ compared with 2011.

Macao's population is aging, and the number of elderly people aged 65 and above has increased by $48.6 \%$ to 59383 , or $9.1 \%$ of the total population, which grew up $5 \%$ in that five years. The percentage of the elderly population and the population of children who aged below 14 increased by $15.6 \%$ to $76.3 \%$. On the other hand, the population aged 55 to 64 (87 583 ) accounts for $13.5 \%$ of the total population and is expected to accelerate further in the next decade.

Compared with 2011, the elderly population increased by $1.9 \%$ (Table 1). The "Trends and Challenges of Population Aging" published by the Macao Statistics and Census Service in August 2014 shows that the population will continue aging, that is, the sum of the juvenile and elderly population who need economic support and the number of working population. The demographic index, dependency ratio that reflects the degree of social aging. At present, 
the gap between fertility rate and the life expectancy, structured the aging population, the dependency ratio will steadily increase to $38.6 \%$ at the end of 2036, the median age of Macao is rising, from 2011 to 2036 . The median age was from 38.1 to 45.5 years (Table 2). Elderly population refers to the above-mentioned population aging issues so that the Macao SAR government concerned about the future of the elderly, and the government's financial burden is increasing, a problem of insufficient pension payment. If the dependency ratio rises substantially, the burden on the working population may be exacerbated.

Table 1. Macau's population ratio from 2011 to 2016

\begin{tabular}{l|c|c|c}
\hline Year & 2011 & 2016 & Change \\
\hline Children population (0-14 age) & $12 \%$ & $12 \%$ & -- \\
\hline Workforce population (15-64age) & $80.8 \%$ & $78.9 \%$ & $-1.9 \%$ \\
\hline Elderly population ( $\geqq 65 a g e)$ & $7.2 \%$ & $9.1 \%$ & $+1.9 \%$ \\
\hline
\end{tabular}

Table 2. Dependency Ratio of Macao from 2006 to 2036

\begin{tabular}{l|c|c|c|c|c|c}
\hline Year & 2011 & 2016 & 2021 & 2026 & 2031 & 2036 \\
\hline Dependency ratio & $10.5 \%$ & $14 \%$ & $22 \%$ & $30.2 \%$ & $36.5 \%$ & $38.6 \%$ \\
\hline Median age & 38.1 & 39.3 & 40 & 41.7 & 43.7 & 45.5 \\
\hline
\end{tabular}

\section{Public Policy Analysis Theory}

Public policy analysis is mainly to solve the social problems in a scientific way, which can be divided into three aspects: politics, public policy and public administration. Through political and moral to make society a good development, the implementation of equality and justice. Through the citizen's strength and participation so that public policy can be effectively developed.

\subsection{The Relationship between Public Policy and Politics}

William N Dunn (2011) mentions public policy can be triggered by social problems or by the direction of government to develop, public policy is to solve public problems-oriented. The essence is influenced by historical reasons, political structure, political background, and social mainstream thought.

\subsection{Public Policy Type}

Thomas A.Birkland (2001) claims that the public policy can be divided into the following categories:

I. Regulatory policy: The authorities act in the form of a law or policy to guide a government or a group. The authorities set a number of principled provisions by the various government agencies / groups to take action on their own.

II. Distributive policy: The authorities divide their interests into unprincipled policies.

III. Redistributive policy: The authorities reallocate interests through relevant policies. 


\subsection{Policy Cycle}

Christoph Knill and Jale Tosun (2011) claims the definition of the public policy cycle can be divided into "Social Issues", "Public Concern", "Agenda Setting", "Policy Planning", "Policy Implementation", "Policy Assessment", "Policy Continuity, Modification and Termination". Through the citizen's strength and participation so that public policy can be effectively developed.

The social problem is a kind of compound process that needs to be solved by a variety of policy tools, which is a kind of social situation that can be improved by collective action.

Public concern of the social problems, often subject to the government attention, mainly because the public interests are affected, affecting the social level, may also be due to social injustice, involving illegal acts, by the social power of the impact of unity and other levels. When a social problem is concerned, the government has to deal with it.

The agenda set up to discuss the relevant issues, for the parties to discuss the potential crisis, the parties to the policy makers will hold different views, the role of government is to balance the demands of all sides. Agenda set usually by the elite, rich class, the legislature, the government, civil society organizations began.

Policy planning is a tool to solve the problem. For example, the Hong Kong Government uses subsidy to support the affected households to install the water filters. The relevant policy is to identify the source of lead water and to know the facts after the legislation to be regulated. Policy planning is broadly consistent with utility, effectiveness, responsiveness, accountability, moral value, legitimacy, transparency, fairness and justice.

Policy enforcement is through the authority of the relevant parties to remedy, through the establishment of various political resources, interpretation, publicity, experimentation, coordination and control and other actions, the contents of policy ideas into practical results in order to achieve the development process activities of the policy objectives.

Policy implementation process mainly includes policy advocacy, policy decomposition, material preparation, organization preparation, policy implementation, comprehensive implementation, coordinated monitoring.

Policy assessment is for the achievement of the target, the introduction of scientific data demonstration, through effective and credible indicators of measurement, such as satisfaction survey through the implementation of the policy before and after the assessment.

Policy continuity, modification, termination of the impact of the impact of the effectiveness of the public, the alternation of political parties, mainstream ideas, the government's financial situation and so on. The policy is optimized through continuous corrections, and if the final policy is to be terminated, it should also consider its enforcement methods, such as Big Bang or Long Whimper.

\section{Pension System}

The three pillar models proposed by the World Bank in 1994 lay the foundations for the 
pension system around the world. However, due to the general lack of protection of elderly, making these three pillar-based security models, has been unable to cope with the increase in life expectancy and changes in demand for the economy. As a result, the World Bank's experts revised the construction of the safeguards hierarchy and presented the study of the Old-Age Income Support in the 21st Century in 2005 to develop a five-pillar model in response to the different conditions of each country.

\subsection{Three Pillar Model Pension System}

The three pillar models include the Publicly Managed Pillar, the Privately Managed Pillar and the Voluntary Pillar. In general, the three pillars of the pension system refer to the three pillars of the social insurance system, corporate pension system and personal savings, including mandatory public management for reallocation functions and the source of income from taxation. For the compulsory private management of the saving function and the source of resources from the fully allocated pillar; for the elders with more protection of the voluntary pillars (Lin Huifen, 2003). In summary, the above three pillars of the security system, if according to its intended goal to distinguish between the first pillar to protect the public pension is mainly focused on the redistribution of social wealth function; as the second pillar of the private pension and third Pillar-protected personal insurance savings system, both of which emphasize the function of savings or insurance.

In the planning of the World Bank, the three pillars of the financial resources and their treatment (Table 3) are also different. The first pillar is the public pension, while the second pillar is the private annuity with the third pillar of the individual commercial insurance, then emphasizes the full deposit of the financial treatment.

Table 3. Three pillar model pension system

\begin{tabular}{l|l}
\hline Pillar & Definition \\
\hline First pillar & $\begin{array}{l}\text { The pillars of compulsory public administration, with the payment of } \\
\text { payment to determine the payment system to provide the minimum } \\
\text { annuity protection. }\end{array}$ \\
\hline Second pillar & $\begin{array}{l}\text { Compulsory from Job Occupation Retirement system, with the } \\
\text { payment of payment to determine the payment system to better lives. }\end{array}$ \\
\hline Third pillar & $\begin{array}{l}\text { Individual voluntary savings pillar, the source of funds from the } \\
\text { individual, by the individual responsible for the proceeds of } \\
\text { guarantee. }\end{array}$ \\
\hline
\end{tabular}

\subsection{Multi Pillar Model Pension System}

Multi-pillar (five) models were improved by the World Bank in three pillars in 2005. In the two models, the common points are the lower level of protection has a higher fairness; the higher the level of protection is more efficient. The first purpose of the World Bank's proposed primary security is to address poverty and income redistribution, while the second tier of compulsory occupational savings and third-tier of voluntary insurance and savings are based on efficiency considerations. In 2005, the World Bank proposed four criteria for measuring the pension system based on the actual situation of different countries, namely, adequacy, affordability, stability and sustainability (Chen Huidan, Guo Yu, 2010). The World Bank has proposed a new multi-level "old age economic security model", this new model has 
two major characteristics, that is, one is to build and expand the scope of protection. The second feature is the existing three pillar design, expanded to five pillars of the annuity structure. Respectively, the Zero pillar, the first pillar, the second pillar, the third pillar and the fourth pillar as showed (Table 4).

Table 4. Multi-pillar model pension system

\begin{tabular}{l|l|l}
\hline Pillar & Definition & Example \\
\hline Zero & $\begin{array}{l}\text { The non-paid based social assistance system or } \\
\text { non-payment of the social welfare system applicable to } \\
\text { the government tax revenue, is a non-contributory cash } \\
\text { assistance, the purpose of providing the minimum living } \\
\text { guarantee for the elderly. }\end{array}$ & $\begin{array}{l}\text { Basic public pension or } \\
\text { social security. }\end{array}$ \\
\hline $\begin{array}{l}\text { First } \\
\text { Pillar }\end{array}$ & $\begin{array}{l}\text { From the social insurance premium as its main source of } \\
\text { insurance, according to the payment system to } \\
\text { determine the payment system to operate, the main } \\
\text { features of the joint responsibility through the social } \\
\text { re-distribution function, through the inter-generation } \\
\text { income transfer to provide elders have a minimum } \\
\text { standard of living for life. }\end{array}$ & $\begin{array}{l}\text { Public mandatory } \\
\text { linked to earnings. }\end{array}$ \\
\hline $\begin{array}{l}\text { Second } \\
\text { Pillar }\end{array}$ & $\begin{array}{l}\text { Occupational savings of specific enterprises or } \\
\text { institutions. } \\
\text { The establishment of the central provident fund system } \\
\text { and the provident fund personal account, the } \\
\text { government-led investment, it means that government is } \\
\text { responsible for monitor, trust, investment and } \\
\text { administration, which is different from the private } \\
\text { management model. }\end{array}$ & $\begin{array}{l}\text { Private mandatory, } \\
\text { Occupational pension } \\
\text { fund. }\end{array}$ \\
\hline $\begin{array}{l}\text { Third } \\
\text { Pillar }\end{array}$ & $\begin{array}{l}\text { This type of annuity system, whether it is a professional } \\
\text { pension system or an individual annuity, is a voluntary } \\
\text { pre-existing deposit reserve system. The aim is to ensure } \\
\text { aclear retirement goal. The forms of pension payment } \\
\text { adopted are covered by private sector insurance } \\
\text { agencies to provide long-term protection. }\end{array}$ & $\begin{array}{l}\text { Voluntary fully-funded } \\
\text { system. } \\
\text { Personal funds, }\end{array}$ \\
\hline Fourance and savings. \\
Pillar & $\begin{array}{l}\text { Family support is level of protection of non-working } \\
\text { family members to provide life care. Due to the } \\
\text { retirement of resources and their consumption } \\
\text { expenditure, not from the formal system of annuity } \\
\text { payments, there are some from the child's support, own } \\
\text { homes, family transfer or personal savings and so on. }\end{array}$ & $\begin{array}{l}\text { Support outside formal } \\
\text { pensions. Family }\end{array}$ \\
support.
\end{tabular}

\section{Individual Accounts of the Central Savings System}

Individual Accounts of the Central Savings System is a kind of welfare for Macao residents. The policy aim is for the retirement planning. Macao government will give a surplus distribution according to government's yearly revenue for Macao residents who meet the requirements that take into it own Fund account.

\subsection{Special Allocation from Budget Surplus}

In the case of the implementation of the budget for the calendar year, the provident fund personal account owner who is still alive on the first day of the publication of the special allocation amount for the calendar year, and who will meet the following requirements in the preceding year as surplus distribution: 


\section{Macrothink}

Journal of Public Administration and Governance

I. Permanent residents of the Macao Special Administrative Region;

II. Over twenty years old;

III. At least 183 days living in the Macao Special Administrative Region.

IV. The prescription for the account owner to claim his/her entitlement to the allocation of funds is three years, commencing on 31 December of the year of fund allocation.

V. The personal account owner of the provident fund is also deemed to be in the time of the Macao Special Administrative Region during the relevant calendar year for the following reasons, provision with sufficient proof on its own.

VI. In general, the owner of the provident fund at the age of 65 may withdraw all or part of the funds recorded by his account.

VII. The provident fund personal account shall be canceled only if the owner's death is committed.

\subsection{Applicants Approved for Withdrawal}

According to the website of the Social Security Fund, data in the third quarter of 2016 show that the amount of the approved extraction has reached 361554 , the cumulative number is as follows:

Table 5. Applicants approved for withdrawal

\begin{tabular}{l|l|l}
\hline The number of applicants who have & been approved for withdrawal & 945 \\
\hline \multirow{4}{*}{ Number of persons allocated } & Appropriation for 2010 & 296050 \\
\cline { 2 - 3 } & Appropriation for 2011 & 307090 \\
\cline { 2 - 3 } & Appropriation for 2012 & 322930 \\
\cline { 2 - 3 } & Appropriation for 2013 & 336928 \\
\cline { 2 - 3 } & Appropriation for 2014 & 348769 \\
\cline { 2 - 3 } & Appropriation for 2015 & 358021 \\
\cline { 2 - 3 } & Appropriation for 2016 & 361554 \\
\hline
\end{tabular}

\subsection{Personal Income Account}

The above data show that the number of persons allocated for provident fund personal account, with interest rate of return of $0.1363 \%$ (that is, the annual interest rate of $1.6356 \%$ ), the income calculation period from September 2015 to August 2016.

The interest income of the provident fund personal account is generated by bank's time deposit, and the distribution income in the individual account is equal to the sum of the balance of the last day of the month in the calculation period.

\subsection{Non - Mandatory Central Provident Fund}

The Executive Council of Macao, which completed the discussion of Non-Mandatory Provident Fund System in June 2016, recommended that the Central Provident Fund (MPF) system be implemented in a non-coercive manner. The legislative intent was to ensure that employees' retirement life would be better protected. 
The draft suggested that Macao residents who have reached the age of 18 or who have been registered under the Social Security Fund will automatically become the owner of the above mentioned provident fund. And the individual accounts are under government administration, contributions and reservations. Only after the commencement of contributions, we can use our own Individual account balance to purchase funds.

Individual accounts are portable, even if the employee terminates the labor relationship, the balance of the contribution will not be settled and will be transferred to the reserved account. Under normal circumstances, the account owner can not withdraw before the age of 65 , and if the contributor retires at the age of 60 or has an urgent need, he may apply to the fund for payment in advance.

\subsubsection{Contribution Plan}

Equality Contribution Scheme and Individual Contribution Scheme. Joint contribution plan refers to the joint contribution of both employers and employees, the monthly contribution of labor is $5 \%$ of the employee's monthly basic salary, and the minimum contribution is $\$ 500$ in MOP (Macau Dollar, the same below). If the employee's basic wage which after deduction is below \$ 6240 monthly (the minimum wage), the employee will not be required to contribute, but the employer will still be required to pay the contribution. If the employee's basic salary is higher than \$ 31200 (five times the minimum wage), both employers and employees are not required to pay the excess contribution.

On the basis of the Individual Contribution Scheme, Macao residents who are above aged 18 are required to apply for establishment. Employees who have participated in the co-contribution scheme can also participate and are exempted. The minimum monthly contribution is $\$ 500$.

\subsubsection{Equity Attribution Ratio}

Proposes to use the "Equity attribution" approach to calculate the share of the employer's contribution at the end of the labor relationship. The current scheme is based on a 3-year period. If the contributory term reaches the first 3 years, the employee is entitled to $30 \%$ of the contribution of the employer's contribution, after that will be increased $10 \%$ per year, and $100 \%$ of the employer's contribution for 10 years or more rights and interests. Within the first 3 years of the commencement of the law, the employer's contribution will be subject to an additional 2 times of tax-free allowance.

\subsubsection{Linking a Private Pension Model}

The draft resolution proposes to implement linking the existing pension to the prior, the employees who have joined the private pension scheme before the implementation of the law, and freely choose to join the central provident fund system and follow some of the original terms. The newcomer will be able to join the system and comply with the rules when the employer enters the system. The private pension and the accumulation of central provident fund has two forms of freezing and transfer, the contribution period will continue to calculate. 


\subsubsection{Options}

In terms of options, they can be divided into co-contribution schemes and personal contribution schemes. The co-contribution scheme will be selected by the employers and employees will have the right to choose a pension fund scheme. When the employee contributes up to 10 years, the employer's pension fund is transferred to the employee's choice. In the personal contribution program, the management entity, the fund plan and the allocation of funds are selected by the account owner.

\section{Conclusion}

The Contribution of central provident fund system is an important policy, especially Macao has entered the aging society, the Macao government must urgently deal with the construction of central provident fund. In Hong Kong, for example, the Hong Kong Government has formally implemented a retirement protection policy on December 1, 2000, with the provident fund schemes (MPF) for 18-65 years of employers and employees in Hong Kong. Employers and employees jointly set up a fund, in general, employees who are 65 years old or individual reasons, can obtain contributions for retirement purposes. In Hong Kong, after the establishment of more than 10 years, there is criticism that the fund return rate is low and administrative costs are expensive, failed to achieve the protection effect, the voice proposed government should be a comprehensive review or even canceled. For the implementation of the "Non-Mandatory central provident fund" in Macao, the Chairman of the Social Security Fund said that the first stages' implementation was enforced by taking into account the short-term economy's adjustment and legislation process. It will increase the pressure on SMEs to operate, while the employees demand mandatory (not only non-mandatory) way to implement the central provident fund system. The Government determined only a few company will join the fund, approximately $4 \%$, while the government is difficult to estimate how many employers will join the program. At present, the Government has not implemented a timetable for enforcement and decision on the basis participants' economic situation. From this perspective, the implementation of the provident fund in Macao still remain in the pilot stage, there is no full implementation of the determination, the Government needs to put more resources to implement the central provident fund system.

Review provident fund system in other countries, for example, the provident fund is biased towards the sound investment projects, the pursuit of lower risk and reasonable potential return. Of course, risk is proportional to the return, so low risk naturally accompanied by low returns, most of the provident fund is difficult to catch up with inflation, facing the actal problem of purchasing power devaluation. Therefore, after the establishment of the central provident fund system, the management and operation faced the same situations.

In the end, there is an important reform in 2017, which, in accordance with the law, provides that the investment in Hong Kong's MPF (in line with the non-mandatory central provident fund of Macao). From April 1, 2017, each MPF scheme must provide a default investment strategy ("Default Investment Strategy"). Default Investment Strategy is an important reform of the MPF system. It aims to provide better retirement protection for scheme members and to respond to the problem of high fees and difficult selection of MPF funds. If the scheme 
member does not give investment advice to the trustee for its MPF, the MPF will automatically invest in the "default investment", which is composed of two hybrid asset funds, namely the core accumulation fund and the pension fund. There has three characteristics, namely, the use of global diversified investment, with the program members close to retirement age and automatically reduce the risk and has a ceiling. The default investment states that the Hong Kong Government has lowered its retirement risk for stakeholders who do not have the relevant risk knowledge.

\section{References}

Christoph, K., \& Jale, T. (2005). Public Policy A New Introduction. Publisher: PalGrave Macmillian.

Macao Department of Communication. (2016). Draft of Central Provident Fund System

Macao Social Security Fund. (2016). Non-Mandatory Central Provident Fund System Consultation Paper.

Macao Statistics and Census Service. (2016). Trends and challenges in Aging Population.

Macao Statistics and Census Service. (2017). Detailed Results of 2016 Population By-Census.

Mandatory Provident Fund Schemes Authority. (2017).MPF Annual Report 2016-2017, Hong Kong S.A.R.

Ming, C. L. (2014). A Study of Labor Old-Age Income Security. National Policy Foundation, Taiwan.

Muxing, K., \& Jiancheng, L. (2005). The World Bank's Multi-Pillar Approach. National Policy Foundation, Taiwan.

Shi, P. G. (2011). The Performance and Value at Risk of Retirement Funds in Taiwan and Hong Kong, Shih Chien University, Taiwan.

Shuho, Z. (2012). A Study on the Economic Security Problems of the Public Pension Schemes in Macao.One Country Two Systems Research, 2, 176-183.

Thomas, A. B. (2011). An Introduction to the Policy Process (3rd ed.).New York: M.E. Sharpe.

Tsan, L. H. (2011). The influence of the restructure of National Pension Insurance and the Labor Insurance on labor retirement income in Taiwan. Macau University of Science and Technology.

Wai, T. C., \& Yu, G. (2010). A Comparative Study of Pensions System in Hong Kong and Macao. Macao Polytechnic Institute.

William, N. D. (2011) Public Policy Analysis (5rd ed.). United Kingdom: Routledge. 


\section{Copyright Disclaimer}

Copyright for this article is retained by the author(s), with first publication rights granted to the journal.

This is an open-access article distributed under the terms and conditions of the Creative Commons Attribution license (http://creativecommons.org/licenses/by/4.0/). 